\title{
Inverse correlation between baseline inhibin B and FSH after stimulation with GnRH: a study of serum levels of inhibin $A$ and $B$, pro alpha-C and activin $A$ in women with ovulatory disturbances before and after stimulation with GnRH
}

\author{
Fritz W Casper, Rudolf J Seufert ${ }^{1}$ and Kunhard Pollow \\ Department of Experimental Endocrinology and ${ }^{1}$ Department of Obstetrics and Gynecology, Johannes Gutenberg University Mainz, D-55101 Mainz, \\ Germany
}

(Correspondence should be addressed to F W Casper, Department of Experimental Endocrinology, Langenbeckstrasse 1, D-55101 Mainz, Germany; Email: casper@mail.uni-mainz.de)

\begin{abstract}
Objective: Interest has focused recently on the influences of the polypeptide factors inhibin and activin on the selective regulation of the pituitary secretion of gonadotropins.

Design: Measurement of the concentrations of inhibin-related proteins in relation to the changes in pituitary gonadotropin (FSH, LH) parameters, after GnRH stimulation with a bolus injection of $100 \mu \mathrm{g}$ gonadorelin, in 19 women with ovulatory disturbances.

Methods: Serum levels of inhibin A and B, activin A, and pro alpha-C were measured using sensitive ELISA kits.

Results: Within $60 \mathrm{~min}$ after GnRH stimulation, FSH values doubled from 5 to $10 \mathrm{mU} / \mathrm{ml}(P<0.001)$. LH increased 12 -fold from 2 to $24 \mathrm{mU} / \mathrm{ml}(P<0.001)$. Activin A showed a significant decrease from 0.47 to $0.36 \mathrm{ng} / \mathrm{ml}(P<0.001)$, whereas pro alpha-C increased from 127 to $156 \mathrm{pg} / \mathrm{ml}(P=0.039)$. The median inhibin A concentration did not show a significant change between baseline and the 60 min value, whereas inhibin B was characterized by a minor, but not significant, increase in the median from 168 to $179 \mathrm{pg} / \mathrm{ml}(P=0.408)$. A significant inverse correlation $(P=0.014)$ with a mean coefficient of correlation of 0.5516 was found, demonstrating a strong relationship between high inhibin B baseline levels and a small increase of FSH after $60 \mathrm{~min}$.

Conclusion: Our results show an interesting correlation between the baseline inhibin $\mathrm{B}$ and the change in FSH before and after GnRH stimulation. A high baseline inhibin B implies only a minor increase of FSH after 60 min.
\end{abstract}

European Journal of Endocrinology 143 77-84

\section{Introduction}

Intact function of the gonadotropins requires anatomical and functional integrity of the hypothalamic-pituitary unit. Altered gonadotropin secretion, manifesting itself as either a monohormonal or multihormonal defect, can be traced to anatomical and biochemical defects in a given region of the hypothalamic-pituitary axis (1). The WHO classification of ovulatory disturbances encompasses a broad spectrum of disorders (2). In women with secondary amenorrhea, the WHO group I is defined as hypoestrogenic hypogonadotropism. Women with this class of abnormal ovarian function have normal or low concentrations of immunoreactive gonadotropins, normal prolactin and low serum concentrations of estrogen. To distinguish a pituitary from a hypothalamic malfunction, a gonadotropin-releasing hormone $(\mathrm{GnRH})$ test is normally performed. Extensive literature has accumulated concerning the administration of synthetic GnRH as single injections (3-5). These injections give a brief, continually changing stimulus to the pituitary, and test mainly the storage of readily available follicle-stimulating hormone (FSH) and luteinizing hormone (LH). Commonly normal, and sometimes even excessive responses are encountered as evidence of a diseased hypothalamus. Patients presenting with impaired or absent LH and FSH responses are rare; however, characteristically this condition can be observed in pre-pubertal patients with intact pituitary and hypothalamic tumors (e.g. craniopharyngiomas), in some cases of isolated gonadotropin deficiency and in severe anorexia nervosa $(6,7)$. The dynamic regulation of anterior pituitary cell function by the interaction of factors derived from the hypothalamus and the peripheral sex steroids is well documented.

More recently, interest has been focused on the regulatory influences of the ovarian polypeptides such as inhibin $A$ and $B$ as well as activin $A(8,9)$. This family 
of inhibin-related proteins was discovered during the investigation of FSH release. The purpose of the present study was to investigate the serum concentrations of inhibin A and B, activin A and pro alpha-C during the GnRH test and the possible effects of prospective influence from these hormones on the test results.

\section{Material and methods}

\section{Subjects}

This study design included 19 women with hypogonadotropic hypothalamic amenorrhea (age range, 17-44 years). Amenorrhea was diagnosed by clinical features and hormonal parameters. A complete medical history was obtained and a physical examination was performed for each patient. Appropriate routine tests were also performed to rule out internal disease. Thyroid and adrenal functions were intact in all of the amenorrheic patients. Serum LH, FSH, prolactin, estradiol, androstendione, testosterone, dehydroepiandrostenedione sulfate, thyroxine, thyroid-stimulating hormone and cortisol levels were measured with the use of specific assays. Blood specimen were collected between 0800 and $0900 \mathrm{~h}$ from the forearm vein after overnight fasting and bed resting. After centrifugation at $2500 \times \boldsymbol{g}$ for $10 \mathrm{~min}$, the serum was separated and stored at $-20^{\circ} \mathrm{C}$ until it was assayed. None of the subjects had taken any hormones for at least 12 months.

The criteria for the diagnosis of a hypogonadotropic hypothalamic amenorrhea were the following, according to Petraglia et al. (10): (i) Disappearance of menses more than 6 months before the study and no evidence of pregnancy. (ii) Low LH, FSH and estradiol levels, measured in three different samples taken 2 months before the start of the protocol (Table 1). (iii) Serum levels of cortisol, androstendione, testosterone, dehydroepiandrostenedione sulfate, thyroxine, thyroidstimulating hormone and prolactin all within normal. (iv) No remarkable psychiatric problems. (v) No changes in sella turcica topography.

To distinguish a pituitary from a hypothalamic malfunction, a GnRH test was performed. GnRH (100 $\mu \mathrm{g}$ gonadorelin, LHRH; Ferring, Germany) was administered i.v. by rapid injection in a single dose. The test was performed after an overnight fast between 0800 and $1000 \mathrm{~h}$. Blood was obtained at time 0 to establish a basal hormone level and at time $60 \mathrm{~min}$ post-GnRH

Table 1 Serum hormone levels in the group of 19 patients with hypogonadotropic hypothalamic amenorrhea.

Hormone level (mean \pm S.E.M.)

\begin{tabular}{ll}
\hline FSH $(\mathrm{mlU} / \mathrm{ml})$ & $2.31 \pm 0.48$ \\
$\mathrm{LH}(\mathrm{mlU} / \mathrm{ml})$ & $1.99 \pm 0.33$ \\
Estradiol $(\mathrm{pg} / \mathrm{ml})$ & $28.3 \pm 8.30$ \\
\hline
\end{tabular}

application. The blood was allowed to coagulate for $30 \mathrm{~min}$, and then centrifuged to separate serum. The serum was quickly frozen in liquid nitrogen and stored at $-80^{\circ} \mathrm{C}$ until analysis.

\section{Blood measurements}

Serum levels of inhibin A and B, activin A, and pro alpha-C were measured using sensitive commercially available ELISA kits (Serotec, Oxford, UK). The kits had the following measurable ranges: concentrations of inhibin A 3.9-500 pg/ml, inhibin B 15-1000 pg/ml, activin A $0.078-5.0 \mathrm{ng} / \mathrm{ml}$, pro alpha-C $1.56-200 \mathrm{pg} /$ $\mathrm{ml}$. Variation coefficients for these assays were less than $10 \%$ for inhibin A, less than $7 \%$ for inhibin B, less than $7 \%$ for activin $\mathrm{A}$ and less than $8 \%$ for pro alpha-C. The specificity of the antibodies was high.

Serum levels of estradiol were measured by RIA (ICN Biomedicals, Costa Mesa, CA, USA).

\section{Statistical analysis}

Data were analyzed by the SAS 6.12 for Windows program to determine statistical significances of differences for each data set. In addition to using the dependent Wilcoxon test to describe the differences between baseline data, and the data at time $60 \mathrm{~min}$ (average, median, standard deviation, $P$-value), an analysis of the ordinary least-square was performed to test the strength of correlation.

\section{Results}

The results of the serum concentrations of FSH, LH, pro alpha-C, activin A and both inhibins are represented in Figs $1-3$. The boxplots show the median, minimum and maximum results, as well as the 25 th and 75 th percentile. The median values verify that within $60 \mathrm{~min} \mathrm{FSH}$ values doubled from 5 to $10 \mathrm{mU} / \mathrm{ml}$ $(P<0.001)$ as shown. LH increased 12-fold from 2 to $24 \mathrm{mU} / \mathrm{ml}(P<0.001)$. Activin A showed a significant decrease from 0.47 to $0.36 \mathrm{ng} / \mathrm{ml}(P<0.001)$, whereas pro alpha-C increased significantly from 127 to $156 \mathrm{pg} /$ $\mathrm{ml}(P=0.039)$. The ovarian polypeptide hormone inhibin A did not show a significant change between its baseline median level and the median level at $60 \mathrm{~min}$ ( 3.9 to $3.9 \mathrm{pg} / \mathrm{ml}$ ), whereas inhibin B was characterized by a minor, but not significant, increase of its median level from 168 to $179 \mathrm{pg} / \mathrm{ml}(P=0.896)$.

Figure 4 depicts the correlation between the change in FSH (delta FSH) and baseline inhibin B. A significant inverse correlation $(P=0.014)$ with a mean coefficient of correlation of $r=-0.5516$ was found, demonstrating a strong relationship between high inhibin B baseline levels and a small increase of FSH after $60 \mathrm{~min}$. The correlations between delta FSH and baseline inhibin A $(r=-0.225)$, baseline activin A $(r=-0.131)$ and baseline pro alpha-C $(r=0.198)$ 

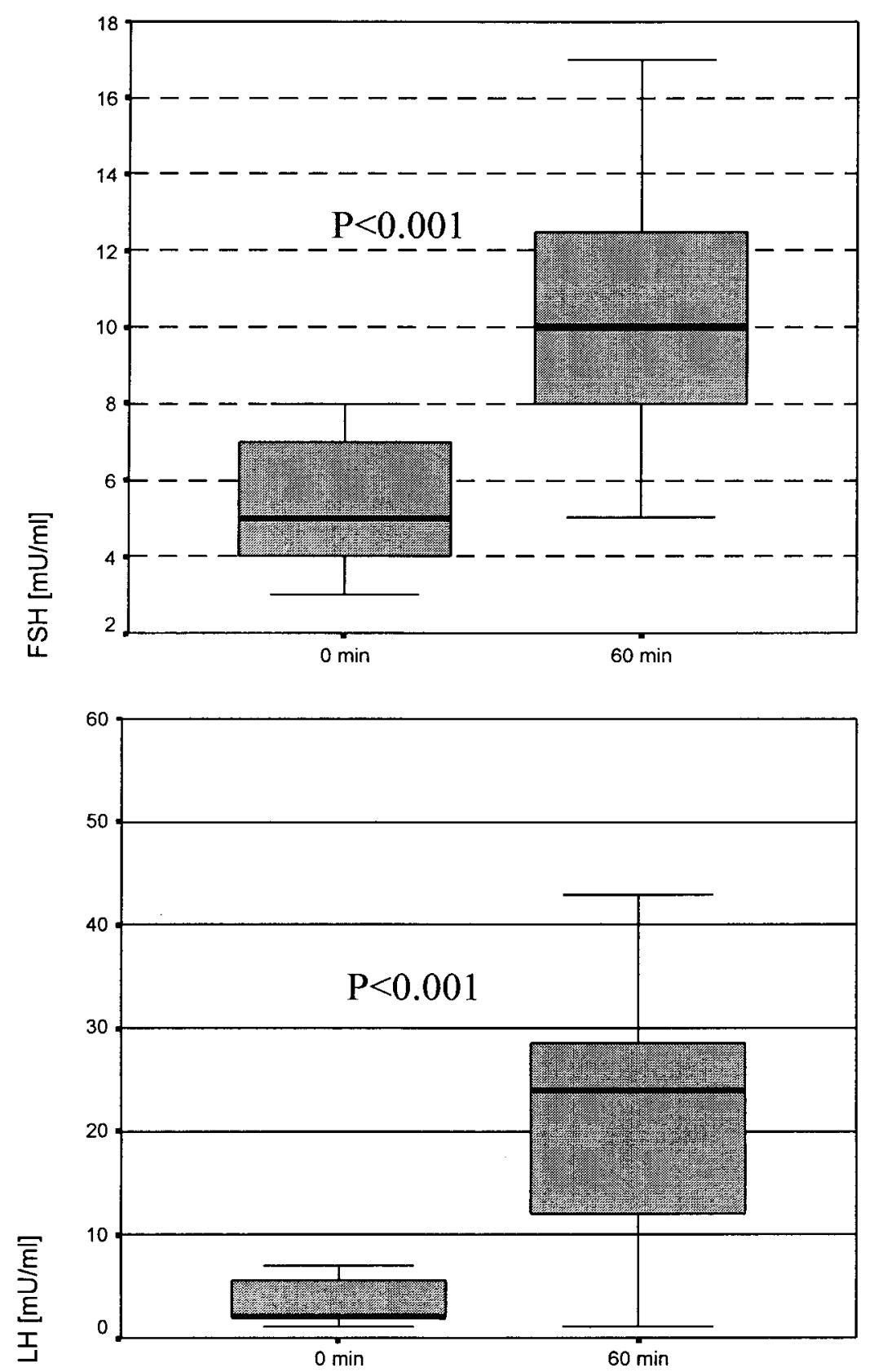

Figure 1 Serum $\mathrm{LH}$ and $\mathrm{FSH}$ values obtained at time 0 to establish basal hormone levels and at time 60 min post-GnRH application in 19 patients with secondary amenorrhea.

were moderate and categorized as not significant $(P>0.5)$. The analyses of the correlations between baseline FSH and baseline inhibin A showed a minor coefficient of correlation of $r=-0.26$, for baseline inhibin B of $r=0.299$, for baseline activin A of $r=-0.126$, and for baseline pro alpha-C of $r=-0.127$.

The Pearson analysis of correlation, with regard to age and baseline levels of FSH and LH, as well for the inhibin group and activin A, showed that there was only a moderate correlation for FSH and LH (correlation coefficients $r=0.283$ and $r=0.228$ ). There was no correlation for inhibin $\mathrm{A}$ and $\mathrm{B}$, activin $\mathrm{A}$ or pro alpha-C $(r<0.03)$ in this regard.

\section{Discussion}

Gonadal dysfunction disorders are clinically characterized by symptoms such as disturbance of the menstrual cycle. On the basis of clinical symptoms, a diagnostic program contains numerous endocrinological, radiological, histological and genetic examinations to determine the level, nature and the pathogenesis of a lesion. 


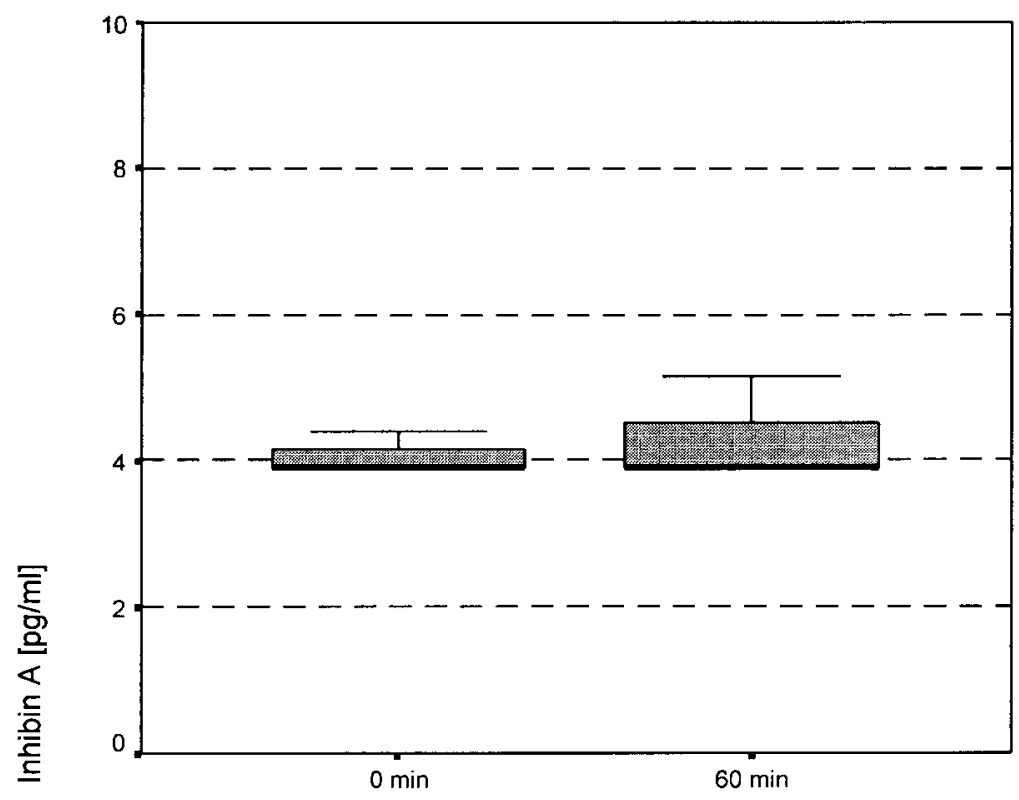

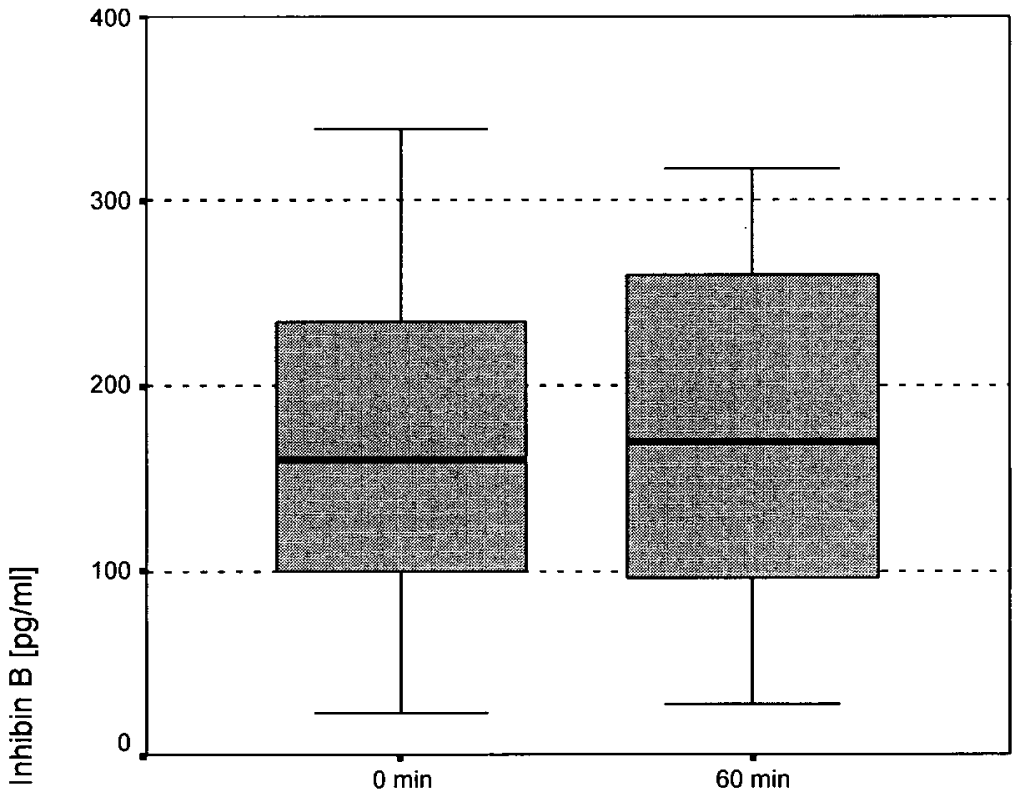

Figure 2 Serum inhibin $A$ and inhibin $B$ values obtained at time 0 to establish basal hormone levels and at time $60 \mathrm{~min}$ post-GnRH application in 19 patients with secondary amenorrhea.
To classify functional amenorrhea several parameters can be measured: baseline gonadotropin levels; the degree of spontaneous fluctuation of LH; the response seen to the administration of clomiphene, which acts principally as an antiestrogen substance on the hypothalamic area; administration of estrogens, which induces only a burst of LH in women hours following its usage; and i.v. GnRH, which liberates the gonadotropins from the pituitary gland (1-6).

Since the development and validation of sensitive and specific two-site enzyme immunoassays were described for inhibin A, inhibin B, pro alpha-C and activin A (11$15)$, interest has more recently focused on the regulatory influences of these polypeptides as selective regulators of pituitary secretions (16). Inhibins and activins are structurally related dimeric proteins, which were isolated and characterized from gonadal sources as a result of an intensive search for non-steroidal feedback regulators of pituitary gonadotropin secretion. Both polypeptides are believed to act solely as classical endocrine hormones (e.g. modulators released by one tissue with effects on a distant tissue, in this case the pituitary). As suggested by their names, inhibin decreases and activin stimulates the production of FSH, generally speaking. What is interesting in this regard are the marked differences in the pattern of 

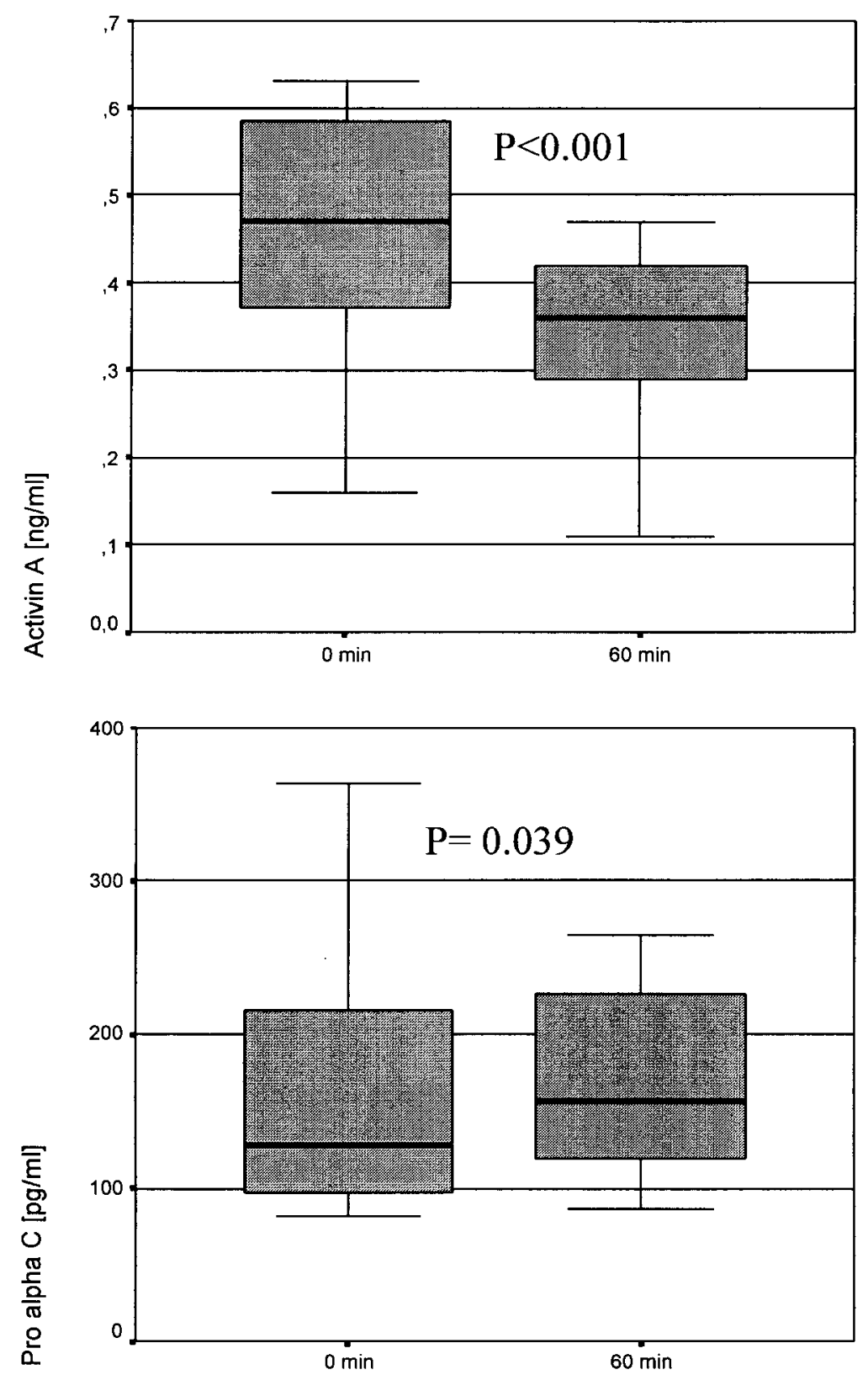

Figure 3 Serum pro alpha-C and activin A values obtained at time 0 to establish basal hormone levels and at time 60 min post-GnRH application in 19 patients with secondary amenorrhea. circulating concentrations of inhibin A and inhibin B during the menstrual cycle. The early follicular phase is marked by an initial reduction in inhibin $A$ that is followed by an inhibin A level that is low but constant in nature. During the second half of the menstrual cycle, there is a marked increase in the concentration of inhibin A parallel to increasing concentrations of estradiol. The readily demonstrable mRNA for inhibin alpha- and beta $_{\mathrm{A}}$-subunits in the granulosa cells of the dominant follicle are consistent with that structure being a major source of inhibin $\mathrm{A}$ in the circulation at that time. In contrast, inhibin B levels continue to rise during the early follicular phase reaching their highest level at the mid-follicular phase of the menstrual cycle. At this point the inhibin B level continuously decreases to the end of the cycle. The demonstration that small antral follicles are rich in alpha- and beta $\mathrm{B}_{\mathrm{B}}$-subunits mRNA is consistent with the recruited cohort of antral follicles being the source of circulating inhibin $\mathrm{B}$ concentrations in the early and mid-follicular phase of the menstrual cycle (17-20). Muttukrishna et al. (21) recently measured endogenous activin A concentrations in peripheral serum throughout the spontaneous human menstrual cycle. Activin A varied in a biphasic manner with higher levels around midcycle and lateluteal/early-follicular phases. Since serum activin A 


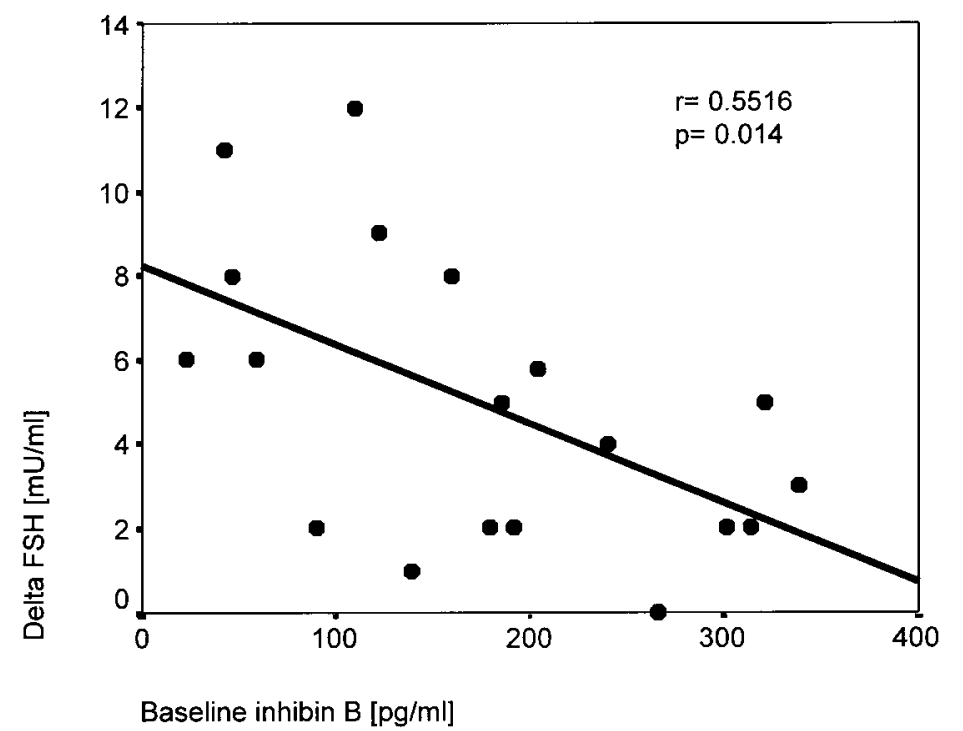

Figure 4 Regression analysis of delta FSH and baseline inhibin $\mathrm{B}$. levels were maximal and inhibin A levels were minimal around the time of the luteo-follicular transition, this could indicate that this pattern is responsible for initiating the development of the next wave of follicles. It is difficult to dissociate the potential contributions of activin and inhibin to $\mathrm{FSH}$ regulation from those of estradiol and progesterone. Both groups fall toward the end of the luteal phase, and are both known to exert negative feedback effects on gonadotropin secretion.

Beyond the control of FSH secretion, there has been some commentary that suggests that these peptides have other diverse, tissue-specific functions. These functions include the modulation of steroid secretion in the ovary and adrenal gland, as well as the regulation of cell growth and maturation in multiple tissues. Also, it has become evident that many of these effects are exerted within the secretory tissue, acting locally either on adjacent cells (paracrine effects) or on the secreting cell itself (autocrine effects) (22-25).

It was the aim of this study to measure the concentrations of inhibin-related proteins in relation to the changes on pituitary gonadotropins (FSH, LH) after GnRH stimulation in 19 women with ovulatory disturbances. As expected, after bolus injection of 100 $\mu \mathrm{g}$ gonadorelin, FSH exhibited a markedly smaller response than LH; FSH values doubled and LH increased 12-fold. Inhibin A concentrations remained unchanged 60 min after stimulation, while inhibin B demonstrated a minor, but not significant, increase. In contrast, activin A levels were significantly decreased. The precursor to the inhibin polypeptides, pro alpha-C, showed a significant increase after GnRH injection. Welt et al. (26) found a positive correlation between inhibin B and FSH in women with normal menstrual cycles during the early follicular phase. Recently, Burger et al. (27) showed that exogenously induced increases in circulating FSH in the follicular phase of the human menstrual cycle resulted in dose-dependent increases in the circulating concentrations of each of the inhibin dimers, A and B. Our results do not directly contradict these findings, but demonstrate only a trend in an increased inhibin B level after a 60 min interval. According to Groome et al. $(17,18)$, the secretion of the biologically active dimeric inhibin $\mathrm{B}$ is closely related to an adequate FSH stimulus. In this study the concentrations of circulating $\mathrm{FSH}$, released through the administration of GnRH, was not sufficient to release readily available dimeric inhibin $B$ in adequate concentrations from the ovarian stores. Moreover, the short FSH stimulation in the GnRH test leads to an increase in the synthesis and secretion of pro alpha-C, which causes dimeric inhibin $B$ to exhibit a delayed synthesis and secretion. These data suggest that there is a critical FSH threshold for inhibin B stimulation. The rate at which $\mathrm{FSH}$ increased seems to be important for stimulation of inhibin B.

Based on the activin A observations, the statements made with regard to regulation through FSH may be conflicting. As mentioned before, Muttukrishna et al. (21) found that the mean serum activin A levels varied during the menstrual cycle in a biphasic manner parallel to FSH serum levels: highest levels around mid-cycle and the late luteal/early follicular phase and nadirs in both mid-follicular and mid-luteal phases. This pattern indicates that there may be a close correlation between FSH and activin A. This observation is in contrast to our finding that activin A levels fell due to the short FSH pulses during GnRH stimulation, and the observation of Lockwood et al. (28) that activin A levels remained unchanged in conjunction with the fall of FSH levels when long-term GnRH analogues were administrated to downregulate the hypophysis. This suggests that the production of activin A is not regulated by FSH. At this junction, it is important to mention that activin 
A has been identified in a variety of extra-ovarian sites and may act as a paracrine factor in numerous biological systems (23-25).

Moreover, our investigation of the response of pro alpha-C to GnRH downregulation produced different results than those described in the Lockwood et al. study (28). Before stimulation with recombinant FSH for in vitro fertilization (IVF) Lockwood et al. (28) measured unaltered pro alpha-C concentrations after pituitary downregulation with GnRH. This regimen of pituitary downregulation creates a hormonal milieu that specifically allows the impact of high doses of FSH on ovarian inhibin secretion to be elucidated. In the Lockwood et al. (28) study, women with normal ovarian function participating in such IVF treatment protocols exhibited significantly suppressed levels of both inhibin A and inhibin B during pituitary desensitization. During stimulation with FSH, levels of both inhibins rose markedly, whereas levels of pro alpha-C were largely unaltered and showed a significant gonadotropinindependent component during IVF treatment.

Recently, Welt et al. (29) demonstrated that reproductive aging is accompanied by decreases in both inhibin $\mathrm{A}$ and inhibin $\mathrm{B}$, and that the decrease in inhibin B precedes the decrease in inhibin A and occurs in concert with an increase in estradiol. This suggest that inhibin B negative feedback is the most important factor controlling the earliest increase in FSH with aging. Klein et al. (30) found that follicular phase inhibin B secretion is decreased in older ovulatory women, whereas inhibin A secretion is similar to that in younger women. The analysis of the age-dependent basal serum level of inhibins and activin done in this study does not support these observations. This study does, however, support the work of Loria et al. (31) who observed no influence of age on serum concentrations of total dimeric basal activin $\mathrm{A}$ in women. When looking at these results, it is important to keep in mind that our patients did not include normally menstruating women.

In conclusion, the significant inverse correlation between the baseline inhibin B and delta FSH before and after GnRH stimulation observed in this study is an important clinical measure: high baseline inhibin B levels imply only a minor increase in FSH after $60 \mathrm{~min}$. The clinical relevance of this observation is that measuring inhibin B in parallel with FSH and $\mathrm{LH}$ can lead to better assessment of the GnRH test.

\section{References}

1 Itskovitz-Eldor J \& Kol S. Disorders of the pituitary gonadotroph. In Reproductive Endocrinology, Surgery, and Technology, pp 12791301. Eds EY Adashi, JA Rock \& Z Rosenwaks. Philadelphia: Lippincott-Raven, 1995.

2 Dodson WC. Adjuctive gonadotropin-releasing hormone analog therapy. In Reproductive Endocrinology, Surgery, and Technology, pp 2183-2213. Eds EY Adashi, JA Rock \& Z Rosenwaks. Philadelphia: Lippincott-Raven, 1995.
3 Keck C, Neulen J \& Breckwoldt M. Endokrinologie, Reproduktionsmedizin, Andrologie. Stuttgart: Thieme, 1997.

4 Roth JC, Kelch RP, Kaplan SL \& Grumbach MM. FSH and LH response to luteinizing hormone-releasing factor in prepubertal and pubertal children, adult males and patients with hypogonadotropic and hypergonadotropic hypogonadism. Journal of Clinical Endocrinology and Metabolism 197235 926-930.

5 Rabe T \& Runnebaum B. Funktionsteste und Untersuchungsmethoden in der Gynäkologie und Geburtshilfe. In Gynäkologische Endokrinologie, pp 47-94. Eds B Runnebaum \& T Rabe. Berlin: Springer, 1987.

6 Berga SL, Mortola JF, Girton B, Suh B, Laughlin G, Phom P et al. Neuroendocrine aberrations in women with functional hypothalamic amenorrhea. Journal of Clinical Endocrinology and Metabolism 198868 301-308.

7 Stoving RK, Hangaard J, Hansen-Nord M \& Hagen C. A review of endocrine changes in anorexia nervosa. Journal of Psychiatric Research 199933 139-152.

8 Halvorson LM \& DeCherney AH. Inhibin, activin, and follistatin in reproductive medicine. Fertility and Sterility 199665 459-469.

9 Woodruff TK \& Mather JP. Inhibin, activin and the female reproductive axis. Annual Review of Physiology 199557 219244.

10 Petraglia F, Hartmann B, Luisi S, Florio P, Kirchengast S, Santuz M et al. Low levels of serum inhibin A and inhibin B in women with hypergonadotropic amenorrhea and evidence of high levels of activin A in women with hypothalamic amenorrhea. Fertility and Sterility 199870 907-912.

11 Knight PG, Muttukrishna S \& Groome NP. Development and application of a two-site enzyme immunoassay for the determination of 'total' activin-A concentrations in serum and follicular fluid. Journal of Endocrinology 1996148 267-279.

12 Robertson DM, Cahir N, Findlay JK, Burger HG \& Groome NP. The biological and immunological characterization of inhibin $A$ and $B$ forms in human follicular fluid and plasma. Journal of Clinical Endocrinology and Metabolism 199782 889-896.

13 Groome NP, Illingworth PJ, O'Brien M, Pai R, Rodger FE, Mather JP et al. Measurement of dimeric inhibin-B throughout the human menstrual cycle using a new ultrasensitive ELISA. Journal of Clinical Endocrinology and Metabolism 199681 1401-1405.

14 Groome NP, Illingworth PJ, O'Brien M, Priddle J, Weaver K \& McNeilly AS. Quantification of inhibin pro-alpha C-containing forms in human serum by a new ultra sensitive two-site enzymelinked immunosorbent assay. Journal of Clinical Endocrinology and Metabolism $1995802926-2932$.

15 Robertson D, Burger HG, Sullivan J, Cahir N, Groome NP, Poncelet E et al. Biological and immunological characterization of inhibin forms in human plasma. Journal of Clinical Endocrinology and Metabolism 199681 669-676.

16 Hayes FJ, Hall JE, Boepple PA \& Crowley WF. Differential control of gonadotropin secretion in the human: endocrine role of inhibin. Journal of Clinical Endocrinology and Metabolism 199883 18351841.

17 Groome NP, Illingworth PJ, O’Brien M, Cooke I, Ganesan TS, Baird DT et al. Detection of dimeric inhibin throughout the human menstrual cycle. Clinical Endocrinology 199440 717-723.

18 Groome NP, Illingworth PJ, O'Brien M, Cooke I, Ganesan TS, Baird DT et al. Detection of dimeric inhibin throughout the human menstrual cycle by two-site enzyme immunoassay. Clinical Endocrinology $199440717-723$.

19 Muttukrishna S, Fowler PA, Groome NP, Mitchell GG, Robertson WR \& Knight PG. Serum concentrations of dimeric inhibin during the spontaneous human menstrual cycle and after treatment with exogenous gonadotropin. Human Reproduction 19949 1634-1642.

20 Roberts VJ, Barth S, Elroeiy A \& Yen SSC. Expression of inhibin/ activin subunits and follistatin messenger ribonucleic acids and proteins in ovarian follicles and the corpus luteum during the human menstrual cycle. Journal of Clinical Endocrinology and Metabolism 199377 1402-1410. 
21 Muttukrishna S, Fowler PA, George L, Groome NP \& Knight PG Changes in peripheral serum levels of total activin A during the human menstrual cycle and pregnancy. Journal of Clinical Endocrinology and Metabolism 199681 3328-3334.

22 Bilezikjian LM, Vaughan JM \& Vale WW. Characterization and the regulation of inhibin/activin subunit proteins of cultured rat anterior pituitary cells. Endocrinology 1993133 2545-2553.

23 Mather JP, Krummen LA, Roberts PE, Gibson U, Mann E \& Stocks D. The role of activin, inhibin and follistatin in the regulation of reproduction in the male. In Inhibin and Inhibin-Related Proteins, pp 223-231. Eds HG Burger, J Findlay, D Robertson, D deKretser \& F Petraglia. Rome: Ares-Serono Symposia Publications, 1994.

24 Eto Y, Tsuji T, Takezawa M, Takano S, Yokogawa Y \& Shibai H. Purification and characterization of erythroid differentiation factor (EDF) isolated from human leukemia cell line THF-1. Biochemical and Biophysical Research Communications 198742 1095-1103.

25 Ogawa Y, Schmidt D, Nathan R, Armstrong R, Miller K \& Sawamura S. Bovine bone activin enhances bone morphogenetic protein-induced ectopic bone formation. Journal of Biological Chemistry 1992267 14233-14237.

26 Welt CK, Martin KA, Taylor AE, Lambert-Messerlian GM, Crowley WF, Smith JA et al. Frequency modulation of follicle-stimulating hormone (FSH) during the luteal-follicular transition: evidence for FSH control of inhibin B in normal woman. Journal of Clinical Endocrinology and Metabolism 199782 2645-2652.
27 Burger HG, Groome NP \& Robertson DM. Both inhibin A and B respond to exogenous follicle-stimulating hormone in the follicular phase of the human menstrual cycle. Journal of Clinical Endocrinology and Metabolism 199883 4167-4169.

28 Lockwood GM, Muttukrishna S, Groome NP, Knight PG \& Ledger WL. Circulating inhibins and activin A during GnRH-analogue down-regulation and ovarian hyperstimulation with recombinant FSH for in vitro fertilization-embryo transfer. Clinical Endocrinology 199645 741-748.

29 Welt CK, McNicholl DJ, Taylor AE \& Hall JE. Female reproductive aging is marked by decreased secretion of dimeric inhibin. Journal of Clinical Endocrinology and Metabolism 199984 105-111.

30 Klein NA, Illingworth PJ, Groome NP, McNeilly AS, Battaglia DE \& Soules MR. Decreased inhibin B secretion is associated with monotropic FSH rise in older, ovulatory women: a study of serum and follicular fluid levels of dimeric inhibin A and B in spontaneous menstrual cycles. Journal of Clinical Endocrinology and Metabolism $1996812742-2745$.

31 Loria P, Petraglia F, Concari M, Bertolotti M, Martella P, Luisi S et al. Influence of age and sex on serum concentrations of total dimeric activin A. European Journal of Endocrinology 1998139 487-492.

Received 26 November 1999

Accepted 17 March 2000 